The Turkish Online Journal of Design, Art and Communication - TOJDAC October 2012 Volume 2 Issue 4

\title{
DIGITALIZATION IN NEW MEDIA: DATING IN DOHA
}

\author{
Jennifer HEEG \\ Texas A\&M University at Qatar, Faculty of Liberal Arts \\ jennifer.heeg@qatar.tamu.edu
}

\begin{abstract}
This project reviews how digitalization has changed the social lives of young adults in the Arab Gulf, specifically in Doha, Qatar. Technologies including Bluetooth, television channels allowing for flirting via text message, and Blackberry messenger services have allowed unprecedented contact between the sexes in a mostly traditional society. By placing this phenomenon in the larger category of "Western," some traditionalists have signalled that Qatari culture is fundamentally challenged by the encroachment of these "Western" behaviors. Simultaneously, Turkish soap operas such as "Noor" are also held up as examples of "Western" infiltration of Qatari society. However, this project seeks to identify the unique ways in which young adults in the Gulf adapt seemingly "Western" technologies, digitalizations, and media formats and use them in ways that are distinctly Gulfi.
\end{abstract}

Keywords: New Media, Digitalization, Qatar, Westernization

\section{INTRODUCTION}

I speak of being afflicted with "Westitis" the way I would speak of being afflicted with cholera. If this is not palatable let us say that it is something akin to being stricken by heat or by cold. But it is not that either. It is something more on the order of being attacked by tongue worm. Have you ever seen how wheat rots? From within. The husk remains whole, but it is only an empty shell like the discarded chrysalis of a butterfly hanging from a tree. In any case, we are dealing with a sickness, a disease imported from abroad, and developed in an environment receptive to it. --Al-e Ahmad, Plagued by the West $(1981,3)$.

This paper will deal with the ways in which particular technologies from "The West" are securitized in Qatari society. First, I must state that Qatar's relationship with the West is not an altogether adversarial one; my ability to conduct research in the various American universities that populate Education City serves as just one example of the ways in which the Qatari regime has engaged and promoted certain types of Western influence in the state.

The quote above was chosen for its literary merit, and not as a general reflection of Qatari perceptions of the West. It was penned in 1962 by Al-e Ahmad, an Iranian author (translated to English in 1981); he was commenting on the phenomenon of "Westoxication" or "Weststruckedness" (Gharbzadegi in the original Farsi) in Iran. When discussing the relationship between Qatar and the West for the past two and a half years with my Qatari students, friends and colleagues, their opinions are decidedly mixed.

For the purposes of this paper, "The West" should be understood as it is understood within the Gulf. This definition may be unusual for those unversed in the region, as it includes not only the United States, Canada, Europe, and other Western societies such as Australia and South Africa, but also most non-Arab and/or non-Muslim societies comprising the higher socioeconomic levels of the expatriate population in Qatar. Interestingly, as Longva (1997:137) notes about Kuwait:

Activities designated as 'Western' were 'Western' and not simply 'non-Kuwaiti' precisely because they could not be identified with the general population of ordinary [unskilled, low-paid] 
migrants. To many, especially expatriates from the Philippines and Goa, drinking, dancing, and mixing between men and women were no more Western than any other social activities. Yet the working-class migrants could not indulge in them because, in Kuwait, such activities took place in private or exclusive settings that were the preserve of the middle class. Thus 'Western' in this context was the particular feature of a social class rather than any national or regional culture. In Qatar as in Kuwait, "Western" is attached to people who are relatively educated, well-paid, and move within middle- and upper-class social circles.

If the emir caters to religious conservatives within Qatar, it is directed more at his citizens and not at a religious elite that would pose a potential political threat. After all, "an indigenous class of local clerics and religious leaders has not developed in Qatar" (Kamrava,2009:409). Kamrava reports that "by all accounts, the state's careful management of religion has so far effectively neutralized Qatari Islam as a potential source of political opposition or even a source of constraint upon state agendas" (Kamrava, 2009:411). However, Kamrava refers exclusively to the institutional factors that would bar a political opposition led by religious clerics to form; this is accurate, but it also discounts the fact that the emir, like all unelected heads of state, is forced either to maintain rule by popular consensus, or to impose it via authoritarian measures.

So, while the Islamic clerics have not mounted a considerable political challenge to the emir, conservative elements do have considerable authority with the majority of the religious Qatari society. The ruling family at times has made concessions, or spoken out on issues that are deemed to threaten Islamic values. Two such examples that will be discussed in this paper are Sheikha Mozah's speech against "immoral" satellite television programming, and her addressing of the boyya trend and establishment of a "rehabilitation center" for homosexuals and crossdressers. Whether or not Sheikha Mozah and the emir believe that satellite television and Turkish programming pose an existential threat to Qatari society is almost irrelevant; these speeches serve to strengthen the ties between the ruling family and its subjects.

Levon Melikian writes:

When cultural pressures are strong and prolonged and come from a culture that is technologically superior, they could represent a threat to national and individual identities... The Arabs of the Gulf were sucked into the vortex of industrial and technological progress (quoted in (Kapiszewski, 2001:144).

The remainder of the paper will address the securitizing effects of two types of technology on Qatari culture: mobile phones and television.

\section{MOBILE PHONES}

Numbers vary, but by all accounts mobile phone penetration in Qatar is over $100 \%$, and even as high at $150 \%$ (meaning there are more mobile phones than there are people living in Qatar). The popularity of mobile phones has had many cultural ramifications in Qatar. Most dramatically, mobile phones have allowed young Qataris to talk to one another clandestinely. In the past ten years, strategies for flirting included males throwing their phone numbers at females while waiting at stop lights or passing them along in shopping malls. They could then talk on the phone, send flirty messages (usually of undying love, full of overly-sentimental poetry and emoticons), and even send photos.

But with the advent of Bluetooth technology, teens and young adults are able to flirt with even less risk of being caught. Bluetooth-enabled phones allow for two people to chat via message over a radio-transmitted signal that is not picked up by the phone company. Now, the boys will 
The Turkish Online Journal of Design, Art and Communication - TOJDAC October 2012 Volume 2 Issue 4

sit or stand in groups at the mall, or drive down the street, and send their phone numbers via Bluetooth to girls they like. Relationships often develop in this way.

\section{The Associated Press reports from Saudi Arabia:}

For the most part, the messages are innocent. But for this conservative society, it is pretty bold stuff. Many images feature babies - some blowing kisses perhaps because women consider them cute. Animated cartoons doing belly dances, dreamy Arabic songs and sappy, sentimental messages are also popular. "Last night I sent an angel to watch over you, but he came back soon," said one message. "I asked him why, and he answered, 'Am not allowed to watch over other angels" ' (Associated Press,2005).

There are ways other than Bluetooth that mobile phones have enabled dating in Qatar. Young women may also see an ad in an Arabic newspaper for a person who sells special mobile phone numbers (to take two very expensive examples, 555-5555 or 123-4567). She may call such a businessman not to buy a number, but because she knows it will most likely be a young Arab man with whom she can talk under the cover of "shopping for numbers." My source, a salesman of such phone numbers, has met two girlfriends in this way, but he also stressed that the proportion of Qatari women who date is still relatively small compared to the conservative majority who would not consider it.

\section{TELEVISION}

While the majority of free-to-air television programming in Qatar is in Arabic, most Arabiclanguage television shows are not fictional comedies or dramas, but instead are programs on Islam (including several live feeds from Mecca and Riyadh), current events, or music/home shopping channels. On the other hand, American programming including "The Simpsons," "Mad Men," and "Notes from the Underbelly" are also available, and most local students are conversant in the recently aired episodes of "Oprah" and "Friends." All of these shows are subtitled in Arabic. Perhaps surprisingly, the two forms of television deemed most offensive in Qatar are in the Arabic language, and indigenous to the Middle East: the development of interactive TV channels, and Turkish soap operas; this subsection will address them in turn.

Interactive television (known as iTV worldwide) includes three broad categories which vary in popularity around the world. At its most general, interactive television allows for the broadcaster and the viewer to communicate with one another. First, interactive TV includes services familiar to American viewers, such as digital video recording (which allows for pausing and rewinding of live broadcasts). Second, interactive TV allows for pay-per-view purchases of particular television programs or films. Third, interactive TV allows for viewers to vote or cast opinions, such as live voting in a news poll. It is this third type of interactive TV programming which has caused a stir in the Gulf, as a genre of television stations have appeared which broadcast flirtatious SMS messages on television (Tech-FAQ 2009). "Just as Arab regimes have come under political pressure thanks to the emergence of Pan-Arab all-news networks, conservative elements of Arab society are now under threat from a lucrative new broadcasting model known as interactive television" (Battah,2006). Indeed, the politics of existential threat to Gulf societies are often invoked by officials when discussing interactive television, signifying that it is highly securitized.

Interactive TV works in much the same way as Bluetooth technology, allowing segregated young males and females to exchange flirtatious messages. The following two images were captured off my home television for illustrative purposes on November 27, 2009: 

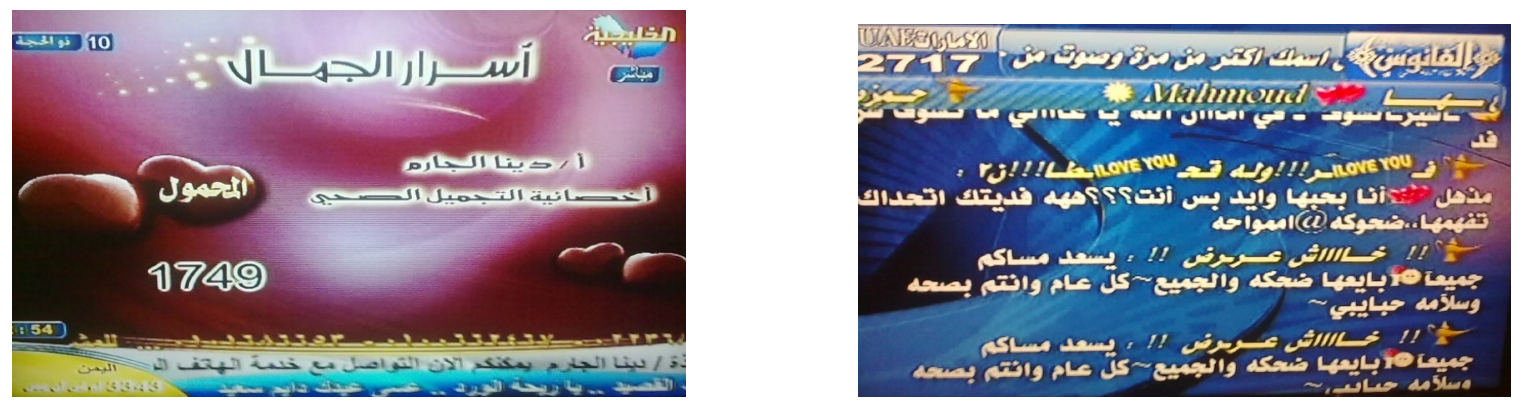

At Zayed University in the UAE in April 2007, an awareness event entitled "Negative Media Threaten National Security" convened, and many Emirati leaders spoke out against interactive TV. Reported the Gulf News, "Our traditions and values are under threat. These vulgar television channels enter our homes and bring us nothing but obscenities. Its owners want nothing but to make profit," said Lieutenant General Dahi Khalfan Tamim, Dubai Police Chief and Chairman of the Juvenile Welfare Association (Saffarini,2007). In another Gulf News article, entitled "Vulgar TV channels "spreading corruption among youth,", featured Lieutenant General Tamim calling such channels "electronic pimps." The article continues:

The police chief warned that if they are not stopped, "every house will lose a son, every mother will lose a daughter, and every house will lose stability. Media ministers and Arab rulers must take up the issue of interactive TV channels."

\section{Destruction}

He said there is a "psychological error" in the minds of the group of people who run such channels, as they do not mind spreading corruption in the society with the aim of destroying it. He said anyone who sells his beliefs, religion, reputation, family and himself, finds it easy to sell his country (Al Theeb,2007).

Interactive television has many critics, to be sure. But the television shows attracting the most controversy and deemed a threat to Islamic morals and society in Qatar and around the Middle East are a new spate of Turkish soap operas, led by the highly-rated "Noor." According to a New York Times article:

"You can't put the consumer back in the box, and the authorities find that threatening," said one Arab television executive, who spoke on condition of anonymity for fear of repercussions. "A generation is growing up, and they watch this stuff and care about it; they upload the characters' faces onto their cellphones" (Worth,2008).

The characters on "Noor" drink wine with dinner, are never shown praying, engage in premarital sex, and one secondary character even had an abortion (Worth,2008). ArabianBusiness.com, a respected news site throughout the Gulf, reported in late 2008 that "The show became a sociocultural phenomenon as three to four million people [in Saudi Arabia] tuned in to Noor every night, making it the highest rated show ever in recent Arab television history" (Sambidge 2008). Indeed, the Saudi-owned MBC network expanded its Turkish soap opera repertoire, and now plays at least four similar programs on a nightly basis on two networks (MBC1 and MBC4). When I returned to Doha in Fall 2009 after spending July and August back in the U.S., I returned to a greatly reduced set of English-language options on free-to-air television; "Noor" and its spinoffs now dominate nighttime programming. 
The Turkish Online Journal of Design, Art and Communication - TOJDAC October 2012 Volume 2 Issue 4

"Noor" is dubbed from Turkish to colloquial Syrian Arabic (rather than the formal classical Arabic of Islamic and news programming), and is not available in English versions (dubbed or subtitled). From an essay written by one of my Qatari students at Texas A\&M University (citing an article from the syllabus):

One of the most recent examples of destructive media is the influx of Turkish series, which recently shows inappropriate life styles that contradict Islamic teachings. Particularly, the Turkish series, Noor, penetrates the social fabric and people name their newborn children after the characters and shops have been selling shirts with their pictures. Turkish movies similar to Hollywood, impacts society because of high technology, nice natural views and movies are more relevant to general features of human conditions (Cowen,2008).

The threat to Qatari society posed by television shows including interactive TV and Turkish soaps led Sheikha Mozah to headline a two-day forum convened in Qatar by the Supreme Council on Family Affairs in November 2008. The forum was entitled (albeit somewhat awkwardly translated from Arabic) "Satellite television channels and the ethical and moral challenges facing Gulf youth." Without being specific as to the types of television deemed immoral and vulgar, Sheikha Mozah supported "a general Arab public opinion that rejects immorality and vulgarity in the media...[and] called on media establishments to sieve through everything they receive for material that represents a violation to general taste." Maryam Al-Khater, Director of the Doha Center for Media Freedom, announced the launch of a website, fadakom.com, that would serve as a forum for Gulf youth to share their opinions on "the dangers of these offensive channels on our values" (Hussein,2008).

\section{CONCLUSION: ON PRESS FREEDOM}

Press freedom has been a topic of heated debate in recent months, even within members of the press themselves. This can be illustrated by discussing just one recent example of tensions between the various media outlets. The publishing in a Danish newspaper (the Jyllands-Posten) of cartoons thought to be offensive to the Prophet Mohamed has inspired an initiative in many Muslim states to ratify an international treaty condemning the defamation of religions. This sparked a row in Qatar after the Doha Center for Media Freedom's founder and then-director, Robert Ménard, invited an editor from the Danish Jyllands-Posten to an international conference on media freedom held in Qatar last year.

Ménard had been outspoken on many issues and forthcoming on what he perceives as the Qatari state's failure to live up to their promises of supporting the Center, but Ménard's invitation of the Danish editor was the issue that attracted perhaps the most sustained negative attention from the Qatari press itself. Ahmad Ali, Editor-in-Chief of Al Watan (a leading Arabic-language daily) wrote that "Ménard should know that there is a red line to media freedom and you cannot cross that border. We cannot accept any media freedom that insults our dear Prophet" (Ali 2009). The Huffington Post reports that Jaber Al Harmi, editor of Al Watan's rival Al Sharq, wrote an editorial with the headline "Ménard lives in five-star style and insults Qatar" (Abu-Fadil 2009). Indeed, it seems the most fashionable thing for editors of Qatari papers to do is to bash Ménard. In late June 2009, after a little over one year, Robert Ménard resigned his post, his team resigned with him, and the Doha Center for Media Freedom folded.

But reverberations continue. Perhaps at least partially as a response to Ménard's invite of the Danish editor, the Advisory Council (majlis al-shura, which advises and consults the emir on policy) argued for increased restrictions on media freedom, specifically with regards to "Qatarbased journalists who write against the ruler, national security, religion and the Constitution," according to Khalid Al Sayed, the Editor-in-Chief of the English-language Peninsula. Sayed 
opposes the Advisory Council ruling - precisely because (according to him) no local newspaper "has ever written anything objectionable against the four subjects referred to in the Advisory Council debate" (Al Sayed 2009). While this may not be 100\% accurate, writing "nothing objectionable" seems to be the goal—-publicly stated or not—of the majority of Qatari newspaper editors. A newspaper reporter told me (not for attribution) that while his paper had always prided itself on its critical perspective (within Qatari parameters), the current Editor-in-Chief "pushes for more positive stories on Qatar" and those are the only ones allowed to be published.

While a private source (who spoke on condition of anonymity) has intonated that governmentsanctioned censorship and detainment of reporters does indeed take place, it is widely accepted and acknowledged that self-censorship (by reporters and academics) does occur on a regular basis. In this environment, the gap between government officials' statements and the newspaper media is very small... and there is a vast ocean between those sources of discourse, and that of critical or anonymous outlets (such as the Qatar Living website and the now-internationally focused Doha Center for Media Freedom). In Qatar, it seems that the more things change...the more they stay the same.

\section{REFERENCES}

Abu-Fadil, M. (2009, June 30). Robert Ménard Slams Door, or Booted Out, of Doha Center for Media Freedom? Retrieved July 1, 2009, from Huffington Post:

http://www.huffingtonpost.com/magda-abufadil/robert-menard-slams-door_b_223300.html Ahmad, J. A.-e. (1981). Plagued by the West (Gharbzadegi). (P. Sprachman, Trans.) Delmar, NY: Caravan Books.

Al Sayed, K. A. (2009, June 11). Advisory Council's Opinion Surprising. The Peninsula . Al Theeb, A. (2007, March 31). Vulgar TV channels 'spreading corruption among teenagers'. Gulf News . Ali, A. (2009, May 6). Editorial. Al Watan .

Associated Press. (2005, August 11). In Saudia Aragia, a high-tech way to flirt. www.msnbc.com . Battah, H. (2006). SMS: The next TV revolution. (A. U. Cairo, Editor) Retrieved November 27, 2009, from Transnational Broadcasting Studies: http://www.tbsjournal.com/Battah.html Cowen, T. (2008). Why Hollywood Rules the World, and Whether We Should Care. In F. J.Lechner, \& B. John, The Globalization Reader (p. 335). Hong Kong: Blackwell. Hussein, O. (2008, November 4). Forum calls for curbs on satellite TV. Gulf Times . Kamrava, M. (2009). Royal factionalism and political liberalization in Qatar. Middle East Journal , 63 (3), 401-420.

Kapiszewski, A. (2001). Nationals and Expatriates: Population and Labour Dilemmas of the Gulf Cooperation Council States. Reading, UK: Garnet Publishing Ltd. Longva, A. N. (1997). Walls Built on Sand: Migration, Exclusion, and Society in Kuwait. Boulder, CO: Westview Press.

Saffarini, R. (2007, April 21). Say no to bad TV. Gulf News .

Sambidge, A. (2008, October 21). MBC expands soap opera shows despite Mufti fury. ArabianBusiness.com . Tech-FAQ. (2009). What is interactive TV? Retrieved November 27, 2009, from http://www.tech-faq.com/interactive-tv.shtml

Worth, R. F. (2008, September 26). Arab TV tests societies' limits with depictions of sex and equality. The New York Times . 